Dr. Kathryn Kraft

Lecturer in International Development

University of East London

School of Social Sciences

Docklands Campus - University Way

London E16 2RD

k.kraft@uel.ac.uk

Religious Exploration and Conversion in Forced Displacement: A Case Study of Syrian

Muslim Refugees in Lebanon Receiving Assistance from Evangelical Christians

Kathryn Kraft, University of East London

Author bio:

Kathryn Kraft is lecturer in International Development at the University of East London. Her research interests include faith and humanitarianism, peace and conflict transformation through storytelling, and capacity building of local civil society, with a particular interest in the Middle East.

Keywords: humanitarianism, conversion, migration, displacement, identity, spirituality

Wordcount: 7512 (6796 without references) 


\title{
Religious Exploration and Conversion in Forced Displacement: A Case Study of Syrian Muslim Refugees in Lebanon Receiving Assistance from Evangelical Christians
}

\begin{abstract}
:
The idea of religious conversion as a break with one's past and a change in identity and belonging, is precarious when considering religious practices in a context of displacement. Forced migrants' sense of identity often becomes volatile when social and political pressures lead them to break with various aspects of their past lives. During a season of displacement, refugees and forced migrants may begin to attend religious meetings of a tradition different to that of their family, or alternately cease engaging in religious activities at all. Using the humanitarian engagement of Lebanese Evangelical churches with Syrian Muslim refugees as a case study, this paper explores some of the unique dynamics in religious engagement in refugee communities. Many Syrian refugees began to attend church and study Christianity, and this did indeed seem to have some sort of "spiritual" influence on them, though few considered making a more radical change in their identity.
\end{abstract}

Religious conversion is often conceptualized as involving a break in identity (Barker and Currie 305), a change to an individual's sense of religious belonging (Thanggaraj 21), and a process that involves shifts in views both of reality and of oneself (Jindra, "A New Model of Religious Conversion" 10). However, conversion studies increasingly recognize that religious conversion is a process that is wrapped up in global movements, characterized by wider political, psychological, social and cultural change (Rambo and Farhadian 2). In a context of forced displacement, this broader change is particularly evident. Though forced migration does not necessarily entail a break with one's former identity, changes in sense of self and 
belonging are perhaps not so remarkable when an individual or family has already had to break with former routines, home and relationships. Furthermore, a person's view of reality and self are often challenged by events that lead to, and result from, his/her displacement.

It is, therefore, helpful to view conversion amongst refugees not as a moment or singular decision, and rather as part of a wider process of change with a fair bit of fluidity and continuity (van Nieuwkerk; Rambo and Farhadian 7). The concept of conversion in these terms is difficult to define, but may be understood as a process of change in a person's life that involves religious exploration. Some refugees may embrace a new faith, begin exploring a new faith, or join a different religious community, but never officially adopt a new identity or religious affiliation as a result of this process of change in their understanding of self as well as in their social relationships.

Then, as refugees who have engaged in a process of conversion begin to rebuild their lives, they may decide to retain their religious identity prior to displacement and revert to the comforts of familiar religious structures. Alternately, they may affiliate to a new religious institution but remain unchanged in their personal convictions, or adopt new beliefs but maintain their former religious affiliations (Zinnbauer and Pargament; Kraft 104; Green 57). It is therefore possible that as a part of the process of displacement and forced migration, many refugees may begin down a road that resembles religious conversion, but few ever come to see themselves as people who have converted religiously. They spend time in the process of "converting", but never describe themselves as "converts".

It is also worth noting that conversion studies have found that people are generally more inclined to convert to a new religion, or explore the beliefs and practices of a new religious group, when they have already renounced, or become disillusioned with, their previous situation (Iannaccone 291; Bourque; Jindra, "How Religious Content Matters" 296). For many refugees, political upheaval has opened a space for general disillusionment with the 
institutions, structures and communities which previously played an important role in their lives. This would suggest that forced migrants are in fact more prone to consider religious conversion, or engage in a process of religious exploration, than they would be had they not been displaced, since their once-familiar sources of stability have been lost.

This paper will explore the experience of Syrian Muslim refugees living in Lebanon, who received humanitarian assistance from, and participated in religious gatherings at, evangelical Christian churches. It seeks to understand the reasons why they may express a growing interest in a different faith during a season of displacement, as well as the nature of spiritual support that Christians may offer to people of a different religion. This refugee engagement in church activities may be conceptualized as part of a conversion process, though is unlikely to result in a large number of people who identify as converts.

\section{About the evangelical-humanitarian response in Lebanon}

Between 2011, when unrest in Syria began, and 2015, approximately 4.2 million of its citizens sought refuge in neighboring countries and 7.6 million were displaced within the country, according to UNHCR. More than half of Syria's population was considered by the United Nations to be in need of humanitarian assistance. Lebanon, the smallest of its neighboring countries, received a particularly large number of refugees. Pre-crisis, its population was approximately 4 million, and more than 1.2 million Syrians registered as refugees in Lebanon between 2011 and 2015. Hundreds of thousands of others did not register as refugees; UNHCR estimates that more than 1.8 million Syrians have now taken refuge in Lebanon, increasing the country's population by almost $50 \%$ within a few short years.

One thing that distinguished the Syrian refugee crisis in Lebanon from many other instances of forced migration, was that no refugee camps were formally established for 
Syrian refugees. While some informal camps, called tented settlements, sprung up, the vast majority of Syrians lived in poor neighborhoods and villages, sharing space and resources with their Lebanese host communities. To accommodate refugees' demand for housing, it was not uncommon for building owners in middle-class Lebanese neighborhoods to rent out storage spaces, boiler rooms or water tank shelters; in more rural areas, chicken shacks and barns were converted into shanty-town style rooms-for-rent.

This population shift brought to light a fair bit of inter-communal tension between Syrians and Lebanese, who have historically held close ties, but for whom roles were reversed in the Lebanese Civil War of 1975-1990, when many Lebanese fled to Syria. Furthermore, during 1975-2005, Syrian military maintained a presence in Lebanon, the memory of which has fueled some tension between Syrian refugees and their Lebanese hosts. With the influx of Syrian refugees, a new type of occupation began, but this time Lebanon found itself in the place of unwitting benefactor. Refugees, most of whom were in dire need of humanitarian aid, and who had been uprooted from their families and communities often after witnessing or experiencing extreme acts of violence, were rarely made to feel welcome in the Lebanese communities hosting them. Reports of classroom violence against Syrian children in Lebanese schools, abuse in the workplace, and ill treatment on the streets of Beirut are common in the Syrian refugee community.

A large-scale humanitarian response began in 2012 to meet the needs of displaced Syrians. Various agencies of the United Nations and international NGOs established or expanded a presence in Lebanon, and more than 2 billion dollars were requested of the international community for 2015 alone. A variety of faith-based actors of diverse religious backgrounds participated in this response, either through formal projects or more informally, using their own resources and networks to help refugees on a case-by-case basis. 
This paper focuses on the response of a local evangelical Christian network. The Lebanese Society for Educational and Social Development (LSESD) comes under the purview of the Baptist Society, and has led a number of educational and social institutions for decades. LSESD launched its Relief and Development department in 2006 to respond to the needs of southern Lebanese displaced internally during the Israel-Hizbollah war. The department remained small for a time, but was beginning to investigate scaling up its development activities in marginalized Lebanese communities when the Syria crisis began. It quickly responded, using its unique combination of relationships, which included Western Christian donors as well as churches in Lebanon to provide support to Syrian refugees. Though LSESD is a Baptist institution, its network included churches of various different denominations.

The data discussed in this paper was collected in tandem with an external evaluation conducted for LSESD in July-August 2014. Six of LSESD's church partners were visited, and interviews conducted with a total of 9 members of LSESD staff, 13 Lebanese church pastors or members involved in refugee assistance, and 21 Syrian beneficiaries. Of the Syrians interviewed, 8 were also volunteers or staff working on the assistance project, and 5 of these described themselves as "believers", that is, converts from a Muslim background who had joined the church. All interviews were arranged by LSESD as a part of the evaluation process and participants were asked permission to use the data from interviews for academic research at the outset of each interview. Interviews were in Arabic or English as per the participant's preference, and took place in churches, the LSESD office or refugees' homes. To the extent that cultural norms allowed, they were private and without other LSESD staff in attendance; the interviewer explained that responses would be kept confidential and would not affect beneficiaries' eligibility to receive assistance or individual staff member's employment. 
At the time of the evaluation, LSESD was receiving funding from an institutional donor to distribute food aid to Syrian refugees through a network of 18 churches spread across Lebanon. Each church received between 14 and 900 monthly supermarket vouchers or food boxes to give to refugee families in their communities, selected according to criteria developed by each church under the close supervision of LSESD. On the scale of the humanitarian response in Lebanon, LSESD's project was small. However, using churches as their distribution mechanism, the project worked in small relatively isolated communities, and primarily with refugees who had not registered with UNHCR and hence were not receiving assistance from the World Food Program, thus filling an important gap. Furthermore, this project was unprecedented in scale for Lebanese evangelicals, few of whom had ever received outside funding beyond small donations from sister churches for church development or evangelistic activities.

Each church was encouraged by LSESD to develop its own distribution modalities, with the caveats that they attempt to assist the most vulnerable refugees living in their communities and that they respect the humanitarian principle of impartiality, that is, that they not provide aid contingent on any affiliation, belief or behavior. In other words, aid should not be conditional on church attendance or any other activity which might be seen as conversionist. It bears noting that many evangelicals in Lebanon avoid using the word "conversion", as it is generally understood to entail a change in sectarian affiliation, a legal process of changing one's official government identity. Indeed, in most countries of the Middle East, with the exception of Lebanon, there is no process for legally converting out of Islam to Christianity at all. Since in Islam an abandonment of the religion is considered to be apostasy, churches typically work hard to avoid suggesting that people pursue this controversial legal recourse. While, as outlined in the introduction, "conversion" is used in this paper to refer to a broader process of change, most of the churches in LSESD's network 
did desire that people make a "decision to follow Christ". This decision would, for most churches, be demonstrated through a public or private declaration of faith in Christ according to the creed of the church, but would not necessarily entail a legal identity change.

Most of LSESD's partners respected the guideline that they adhere to the principle of impartiality, but as a part of their assistance strategies, volunteers who were usually church members visited refugees in their homes to verify need and for project monitoring. On those visits they often shared about their faith, offered to pray with or for refugees, and invited them to Sunday services. When distributions happened at church buildings, they were usually preceded by a prayer and a short greeting from a church leader which may not have been explicitly evangelistic but which did contain religious content.

After starting their food aid programs, most churches reported an increase in attendees at their Sunday services, including many Syrians. Unprecedented was the appearance of Muslim women in hijab at church meetings. Some churches even introduced an additional service or other religious meetings, with content designed to be easily understood by their Muslim attendees, and offered bus services to facilitate refugees' participation. Other churches began home Bible studies, where refugees received more personalized religious instruction. In short, though few claims were made about conversions to Christianity, evangelical Christians in Lebanon celebrated a growing interest in Christianity among Syrian Muslims.

However, as the next section will explore, other humanitarian actors have long expressed concern about aid provision that integrates religious activities with material assistance. Among LSESD's partners, the sincerity or extent of the project beneficiaries' interest in Christianity was not clear, though the holistic care provided by the church did appear to meet emotional needs. The final section will therefore explore ways in which this model of care may be understood as a part of a process of religious conversion that was an 
integral part of beneficiaries' experience of displacement, but for most refugees, without a moment in which they decided to convert.

\section{Humanitarian Accusations}

In Development studies, the role of faith was sidelined for much of the 20th century, even though "missionary organizations associated with the mainstream Christian churches are in many respects the forerunners of modern-day development NGOs in their commitment to the provision of social services and in their support of the poor" (Clarke, "Faith Matters" 843). Indeed, for many Christians, a culture of giving to the poor was borne out of common understandings of the evangelistic call of Christ. "Evangelicals, when rich, thought of their wealth as a stewardship; to be worthy of it, they displayed responsibility for the well-being of their fellow human beings" (Cohen 394). This led to reform movements like anti-slavery, advocacy for women's and prisoners' rights, and establishment of educational and health institutions.

In the 20th century, however, particularly in the wake of World War II, the growth of non-religious humanitarian organizations accompanied an increase in missionary conversionist activity which eclipsed traditional missionary groups' funding, personnel and reach. Meanwhile, a secularist narrative was growing in predominance in political and development circles, which "saw religion as a conservative and traditional force, destined to withdraw and eventually disappear from public life as part of societal progress towards an increasingly modern society" (Jones and Juul Petersen 1292). Religion and humanitarianism came to be seen by many as fundamentally incompatible.

During the past two decades, though, public religion has re-emerged, and more religious activism is being seen in national and global public fora. To some extent, the decline of communism and subsequent upheaval of the 1990s created a space for the 
revitalization of public religion, as previous socialists found their advocacy voice in religious or faith-based narratives (Clarke, "Faith Matters" 843). Meanwhile, the continued and unabated public role of religion in many parts of the world is again being acknowledged by academics and humanitarians. There is a growing recognition of the role faith can, and arguably should, play in development and in humanitarian action.

In the past decade, this new, or renewed, acceptance of the role of religion, has been marked by a series of international conferences on faith in development, and renewed effort by most major institutional donors and United Nations agencies to partner with faithmotivated humanitarian actors. These discussions highlight a number of advantages that faith, or local faith communities, can contribute to meeting people's urgent needs in a situation such as the massive displacement of Syrian refugees to Lebanon. Advantages include local relationships and trust within local communities, deep cultural awareness, a holistic approach to aid provision which integrates a spiritual dimension, passing a sense of hope to beneficiaries of their program, and an independence from political pressures which is likely related to their ability to rely on a strong private funding base (Clarke, "Agents of Transformation?"; James; Kirmani; Lynch).

At the same time, local faith communities are also inherently suspect, mainly due to concerns that they will only help their co-religionists (Ferris; Clarke, "Agents of Transformation?"), or that they may engage in proselytization, that is, exploit people's suffering to recruit them into their religious community (Jayasinghe; James). While there is little concrete evidence that faith-based organizations regularly engage in such rejections of widely-shared humanitarian principles, the activities of evangelical churches are particularly suspect with regards to the second accusation because their conversionist ideology is wellestablished. Historically, Christian missionaries have sought to recruit converts and at times have mistaken polite interest for evangelistic opportunities. The story of Goan Jesuit priests 
who were invited to a Mughal court in the 16th century to share about Christianity illustrates this. Akbar, the Mughal ruler, was interested in learning about Christian teachings and received the priests with warmth and affection, but he did not become a Christian. From the point of view of the Jesuit order that sent the missionaries, therefore, their mission was a disappointing failure in which nothing good happened, even though it did open new avenues for interfaith dialogue and lasting friendships between Jesuits and Mughals (Raj). Though not all Christians see conversion as their sole aim, stories like this one, along with the rise in evangelistic missionary activity during the past century, have reinforced an idea amongst many humanitarians that faith-based organizations, especially Christians who are often associated with colonial endeavors of the past two centuries, are committed to recruiting converts above all else.

In the churches included in this study, even if aid was not conditional on religious engagement, it is true that many did simultaneously engage in evangelism, and there is evidence to suggest that some of their beneficiaries may have felt a degree of social pressure to participate in church activities. Like the Jesuit priests, some church members interpreted refugees' attendance and interest as reflecting a desire to possibly adopt a Christian faith as their own, though others accepted that refugees likely had other reasons for engaging in church activities. Several participants in this research, including church members and LSESD staff, pointed out that if a church stopped providing aid, they expected that most of the refugees attending that church would stop doing so. Similarly, few participants expressed any expectation that refugees would continue engaging in Christian activities when and if they returned to Syria.

This research pointed to a variety of different possible motivations underlying Muslim refugees' apparent interest in Christianity. Among LSESD's beneficiaries, many did use church engagement as a means of accessing aid, but others used aid as an excuse to come to 
church. One church leader estimated that not quite one-fifth of the families receiving food through his church sent someone to church meetings, and only one or two members of each of those families would be in attendance. Since these numbers represented a relatively low portion of their total number of beneficiaries, and based on conversations with attendees, he concluded that many people attending church told their families that they needed to do so in order to access the food aid, thus using aid as an excuse to visit church. A member of LSESD staff explained that he believed there were various reasons for church attendance. Some refugees, he said, attended church "to ensure that they can get the voucher next month. It's not a condition - but they think so. Others say, vouchers or not, we want to hear the word of the Lord... Some of them have been saved. But their decision is their decision." Similarly, a refugee who did describe himself a convert and church member, and who became a distribution assistant working for the church, said, "So many people take advantage of the church and come to church just to get the food. But on the other hand, I have also heard stories like of two brothers who fight over who will come get the food baskets because they both want to come hear the message."

A church leader shared that he and his wife often pondered why so many refugees were attending their church, when the church's volunteers worked so hard to separate distributions from religious activities. They were encouraged, though, when one woman who was attending church but not receiving vouchers actually turned down the offer of assistance that was eventually presented to her, saying that there were other people who needed it more. They concluded from this that, while she may have started attending church hoping to access aid, as she became friends with other refugee women who attended the church meetings, she could not in good conscience accept aid at their expense.

Many church volunteers suggested, however, that motives may not matter. Their churches offered a holistic aid package, and it was up to the beneficiaries to make the most of 
the aspects of the program which met their felt needs. Refugees were accessing life-saving material assistance and also a spiritual message. Many church members, who themselves grew up in wartime Lebanon, wanted to provide care to their beneficiaries that met all their needs, and many saw spiritual needs as being just as important as material needs. These "spiritual" needs included heartfelt desires and concerns which bear some resemblance to what are referred to by secular humanitarians as "psycho-social" needs, involving issues of social exclusion, trauma, abuse or exploitation, and character development.

In a conversation with a Lebanese volunteer, I raised the question whether church services are a form of assistance in their own right. She said, "That's a good question. For some people, they come with anxiety, then they hear the preaching, and they do relax. It gives them hope. Some people are really curious." This sentiment was echoed among many refugees. Some refugee women described both church meetings and distribution events as two parts of one much-appreciated program. On the other hand, for many refugees in destitute circumstances, the urgent need for food and non-food items to ensure daily survival obscured other interests. One woman shared that she eventually came to appreciate that assistance included more than just food or shelter, but "at first, it was the assistance. When I arrived in Lebanon, before we were able to register as refugees, I was so desperate to get anything I could get my hands on. But as I got to know the people in the church, the spiritual side became more important. Now they are in balance with each other."

Church leaders and members were particularly pleased when attendance at their Sunday services swelled, and thrilled when refugees chose to embrace their faith. Most of these churches are, after all, evangelical and prior to the Syria crisis, had conceptualized their entire ministry role as entailing evangelistic and religious teaching. Church activities included Sunday services with preaching and music, Bible studies, Sunday School for children, prayer meetings, and musical events or social gatherings to which members might be encouraged to 
invite non-believing friends, but rarely included charitable work in surrounding communities. A desire to share the message of Christianity with non-believers, nonetheless, underscored many activities of evangelical churches. So, in the humanitarian response, while church members may be committed to not pressuring a refugee to convert, they are still likely motivated by the possibility.

Furthermore, though most churches were committed to helping refugees primarily on the basis of material need, there were some pastors who saw evangelism as their main goal, such as one who told LSESD staff that his church provided aid to Muslim refugees because "they are people who we want to share with." As long as churches respected humanitarian principles regarding non-conditionality, LSESD staff did not challenge such statements, because they understood that evangelistic possibilities helped motivate church partners to continue working tirelessly, providing urgent assistance to people in need. One staff commented, "Would partners agree to expand [their assistance] if it meant being less relational? It's a lot of work for them, and introduces a lot of complication into their existence. In some ways the payoff for them is the 'opportunity' it presents religiously." As stated above, church volunteers observed that only a minority of food beneficiaries attended religious meetings. Though they were few, some of those did take the radical decision to embrace a Christian faith and announce their decision to church members. Again, motivations varied. Some refugees who claimed to have converted, made a faith decision as a result of a very physical benefit such as miraculous healing. One woman, for example, had a son who was ill and the doctors gave her no hope of a cure, but at the church someone prayed for him and he got better. "Then I believed it all," she said. Another woman explained that the church played an essential role in her new life in Lebanon. It was the social acceptance of the church community that was most instrumental in her decision to embrace the faith of the church: "I saw a different love. I wondered why they work with us in this way. Lebanon is 
terrible... We are not treated well here, no one likes us. When you just enter the church, though, it's different. I learned that it's because of Christ. They care about ALL aspects of our life."

Self-proclaimed converts were few compared to the number of refugees attending church, and fewer still compared to the total number of beneficiaries of LSESD's food aid project. Nonetheless, even these small numbers raise doubts as to the integrity of LSESD's partners, whether those individuals genuinely converted, and if so, whether their decision would outlast their displacement. There is also concern that they may have been responding to some form of coercion, manipulation or exploitation of power that comes with aid provision. Such concerns, however, are particularly difficult to address, since they involve the very heart of individual personal experience.

Regardless, there does seem to be some way in which churches' religious activities played a role in beneficiaries' sense of self, belonging and belief. There was some process resembling conversion in the stories of Muslim refugees attending church, which did not point to any indication that those refugees were leaving Islam or embracing Christianity, or in any other way coming to see themselves as "converts". The following section will explore some of the ways in which refugees benefiting from LSESD's project engaged spiritually and religiously with churches as a part of their wider experience of displacement and migration.

\section{Forced migration, displacement and the spiritual needs of refugees}

Evangelistic activities in a situation of massive displacement are surrounded by extensive social upheaval and change, and potential interest among those being evangelized is shaped by a wide variety of social factors. Faith is one of various aspects to a complex sense of identity, and interest in Christianity may be borne out aspects other than faith, such as a desire to learn, expand one's social horizons, or make friends from diverse backgrounds. For 
some, church may provide a much-needed support structure in a difficult season of life; that the church is Christian and the refugees are Muslim matters little. When church members pray for, or share Scriptures with, refugees, this may be received more as a source of psychosocial support than as a form of religious indoctrination. All these things may be part of an attempt by churches to draw people into their community of faith, but they are meeting felt needs in their own right.

Movements of globalization, most notably migration, have led to a greater loyalty among some communities to a sense of group, or collective identity (Smith and Fetner 13). At the same time, though, migration can lead to a greater sense of individuality, especially among people who come from relatively collectivist societies and whose social structures have in some way been disrupted. Individuals may affiliate to a new group or question the groups to which they have previously been affiliated (Modood; Roy).

Displacement can also lead to a sense of loss of self and of the logical coherence which previously explained life. "For the deterritorialized self, social coherence is pursued through... seeking to create and recreate a sense of interactive place, however temporary" (Caldas-Coulthard et al. 2). Religion can be a powerful tool for providing needed explanations, or a means of self-expression, in the light of such upheaval. "The power of religion as a coping device owes to this ability to simultaneously render stressful events intelligible and to point people to specific actions useful in restoring a sense of well-being" (Wessells and Strang 210). When the effects of migration are felt more acutely due to its forced nature, faith-based organizations can help address the sense of upheaval felt by many refugees. Disaster survivors are looking for meaning, an explanation to make sense of the difficulties and losses that they have undergone.

For some disaster survivors, faith is a buffer, while for others, existential questions emerge in the season of crisis and a spiritual struggle is triggered (Aten 134). Therefore, "to 
help strengthen and build spiritual capacity for disaster spiritual and emotional recovery is to help strengthen and build capacity for spiritual and emotional wellness" (ibid 132). Those Muslim refugees who found churches offering answers may well have been interested in converting to Christianity. However, for many more, it was not an issue of conversion, rather it was about seeking support wherever support may be given. Most of the Muslims attending church had not found the support they were seeking at their local mosques or Muslim community associations.

The spirituality of human beings, particularly in contexts such as forced displacement, is increasingly acknowledged both in the academy and among humanitarians. Indeed, the Convention on the Rights of the Child refers to spirituality as an aspect of a child's holistic development. UNHCR's 2014 "Partnership Note on Faith-Based Organizations, Local Faith Communities, and Faith Leaders", states: "Local faith communities are uniquely aware of the fact that, in many countries and communities around the world, faith is a 'basic need' and provides spiritual sustenance for persons of concern to UNHCR. Local faith leaders and faith communities are uniquely positioned for this" (Türk et al. 12). Indeed, it is becoming widely recognized in humanitarian circles that faith-based actors have a key role to play in meeting such needs of affected populations.

However, spiritual assistance is easier to accept in contexts where the affected population share a religion with the faith-based aid providers. Evangelical churches in Lebanon were providing spiritual support as best they know how, but to people of a different religion, most of whom were previously unfamiliar with their faith. There was a conversionist element to this approach, but it was also an expression of compassion for the deeply-felt needs of the refugees they met, using the spiritual tools at their disposal. Refugees, on their part, may have been changed through this experience, but not in a way that made them feel more "Christian". 
Karl Rahner's concept of an "anonymous Christian" may be helpful for conceptualizing the existence of people who have had some experience of, or adhere in some way to the doctrines of, a different religion, but who would not consider themselves to be members of that religious community (Morrow 4). Rahner saw anonymous Christianity as a partial state of being, whereby people had experienced some "grace" which Christians might attribute to Christ, though they did not see themselves as Christians (Morrow 6). Similarly, though engaged in church activities and acknowledging some degree of spiritual change or impact in their lives, most Muslim refugees did not associate this change with an affiliation to Christianity. On one hand, these changes may be seen as part of a conversion process, but few beneficiaries experienced a subsequent break in identity (Barker and Currie 305) or would describe themselves "converts". At most, they took on characteristics of "anonymous" believers, people with some sense of "grace" experienced in worship services or prayer meetings, which may accompany them back to their Muslim community after the urgent material and emotional needs of displacement subside. As Muslim refugees described their church engagement with me, though, the inner peace to which some referred after beginning to attend church meetings was not connected to a desire to "decide to follow Jesus." Instead, it was framed in social or emotional terms.

One of the strongest themes that emerged out of this research is that many Syrian refugees who attended churches in LSESD's network enjoyed learning new things. Many, especially women who typically requested and collected vouchers on behalf of their families, were either illiterate or had not studied beyond primary school, and in their home villages had not met people of different religions. One woman said, "We didn’t know anything about Christianity... We are seeing new things and learning. In Syria, we didn't get out much like this." A Syrian man who did describe himself as a convert and who volunteered at the church, explained that he believed many women, in particular, attended church because there was no 
church in their home region. In fact, he said that most of the women who approached his church to request food, rather than another local aid association, did so out of curiosity. In contrast, he suggested that people who came from parts of Syria that were previously more diverse might have been less interested in learning about Christianity.

One woman who was attending church regularly, but who had not previously known many Christians, explained, "I have learned about Christianity, and what it actually means. I didn't know before. There is lots of shared understanding and values between us - you could say we complete each other." Another said, "I have learned the Injil. This is good because I was curious about everything... No one said that this is your religion and this is mine. They just teach us, and I appreciate this." While they were interested in learning about Christianity, beneficiaries did not generally see this as any challenge to their Muslim identity, merely as an opportunity to learn, experience new things, and broaden their horizons. Though some beneficiaries complained of negative experiences in Lebanese mosques or Muslim associations, many continued their Muslim traditions in the privacy of their homes and saw no tension between those and church participation.

Indeed, church engagement seemed to be promoting more tolerance than conversion. One woman said, when asked if there was not any concern that churches were trying to convert them to Christianity, "It's not a problem for us. At the Life Centre [Church] they teach about faith, and I accept that. We are each free to do what we want; I'm not opposed to it.” Another said, “The most important thing is an open mind. Before, I didn't know who Jesus is, but I wanted to know more, to develop myself culturally.” Many refugees emphasized this new-found sense of freedom: while in Syria it would be considered odd and indeed socially taboo for a Muslim woman to visit a church, in Lebanon they did so openly. They saw this as a rare opportunity, one of the few benefits of the deep suffering and loss they had undergone in the past few years. 
Furthermore, as refugees who attended church were expanding their knowledge and understanding, many were also sharing what they learned with family members or neighbors. This was empowering, especially for women, giving them a teaching role in their community. It was also a source of entertainment for refugees who had little to do, scared to venture out into an unfriendly host community and simply waiting for their circumstances to somehow change.

Church attendance was also helping meet the social needs of people who experienced upheaval by providing social gatherings and a safe space in which refugees could discuss other life problems. A number of LSESD staff and Lebanese volunteers began to describe churches as "community centres", and indeed, some of LSESD's church partners had begun to operate their refugee assistance programs in facilities rented in neighborhoods with high refugee populations rather than using their church buildings.

Many refugees did not begin to attend church services because a church member invited them; rather, it was at the invitation of another refugee, who described church as a social event, that they came. One woman, when asked if she attended church, said, "Yes, I go to the church. I take my kids there for school. I go to the meetings at the distributions, and on Sundays also. Also special events... I like it. I don't know why, but I would go even if no one was there. I feel like if I don't go to church then something is missing from my life." Another woman narrated that, "Sundays have become an event for us. Every Sunday, we get dressed, we bathe the children and put them in nice clothes to go to church." In response to this enthusiasm, some churches have begun to plan special events, such as Ramadan Meals, Mother's Day celebrations, or cinema nights. Refugee women rarely found these social opportunities in Muslim associations, though some did, and most still participated in Muslim religious festivals at home. 
One of the reasons why church volunteers expressed appreciation that refugees were attending church services, was because at these gatherings they were more likely to be able to identify more socially sensitive needs. In particular, volunteers in some churches found that they needed to create a space where women could share about problems with their husbands or other domestic disturbances, or where they could simply cry. One pastor reported that some refugees regularly walked half an hour to reach his church, "just to touch the wall, to feel rest."

Finally, religious engagement provided a form emotional support for refugees who had experienced trauma, or who were experiencing ongoing trauma due to protracted displacement. For example, many church volunteers reported that they prayed regularly with refugees. One Lebanese man said, "On the visits we pray with them. The most important priority of the visit is to pray with them. We also listen to their stories, their experiences, and identify their problems." A Syrian volunteer, who did call himself a convert, said, "Their biggest need is for someone to treat them like a person and to listen. The Bible talks about giving milk to the spiritually young, so that is what we do. The milk is that we listen to them. We hear their stories."

Listening and praying, therefore, met deeply felt needs that touched at the very heart of the pain felt by refugees, and helped them restore some small measure of emotional stability. The means by which church volunteers did these things were distinctly Christian, rooted in the traditions and teachings of their church, understandable considering that they themselves were church members and had been taught to pray and encourage people in certain ways. One church volunteer explained that, because they lacked the skills for providing professional counseling or other specialized support, they chose to do so by providing spiritual support, which was what they, as a church, do well. 
This balance between spiritual and emotional support was referred to by a number of participants in the research, and was something LSESD staff appreciated. Refugees themselves expressed gratitude for spiritual support because of its psycho-social benefits, such as one woman who said, "Now I am learning to be happier, to react better to my situation. There is something new, and I feel that there's love."

Heart for Lebanon, another Christian NGO in Lebanon, published a case study in 2014 describing how evangelical churches had embraced a holistic view of their role similar to that of LSESD's partners. The report's conclusion celebrates that, "Forsaking their pride and following Jesus to serve a community that they previously condemned, the evangelical church not only served the marginalized and broken, but also brought the lost to the Lord" (Heart for Lebanon). Many evangelical Christians in Lebanon have taken note not only of this different and broader role of local churches in meeting humanitarian needs, but also of their growing success in attracting new converts. While some Muslim refugees did in fact declare that they had changed faith, all Syrian refugees were living a season of upheaval, and many were exploring new experiences.

Both the material and spiritual assistance that churches in LSESD's network provided to refugees were indeed meeting felt needs, providing hope and a renewed sense of meaning to families who had lost those fundamental elements of an emotionally healthy life. The number of "converts" may be small, but many embarked on a process that had characteristics of religious conversion. They embraced Christian practices, found encouragement in Christian beliefs, and enjoyed Christian rituals, though without any distinct change to their identity as Syrian Muslims, and even if only for a brief season. Their lives will never be the same, though, and the social and emotional experiences they have had during this season of displacement will stay with them. Churches played a role in their refugee experience, and 
contributed to their changed knowledge and worldview as well as providing them some form of spiritual support in their time of need. Though few may ever call themselves Christian, many may to some extent be described as anonymous Christians, or people who have somehow experienced a lasting change in their hearts even though their engagement with Christianity is only a passing aspect of their wider experience of displacement and their loyalty remains with their Muslim community. The break with their former identity already happened when they were forced to flee their homes, often dodging shellfire; life as a refugee now meant picking up the pieces and building something new. 
Acknowledgements:

This research was conducted in tandem with an external evaluation of the Relief and

Development Programme at the Lebanese Society for Educational and Social Development (LSESD). Thanks to LSESD and its partners for hosting and facilitating all stages of this research.

No potential conflict of interest was reported by the author.

Reference List:

Aten, Jamie D. "Disaster Spiritual and Emotional Care in Professional Psychology: A Christian Integrative Approach.” Journal of Psychology and Theology 40 (2012): 131-135.

Barker, Irwin R., and Raymond F. Currie. "Do Converts Always Make the Most Committed Christians?" Journal for the Scientific Study of Religion 24 (1985): 305-313.

Bourque, Nicole. "How Deborah Became Aisha: The Conversion Process and the Creation of Female Muslim Identity.” Ed. Karin van Nieuwkerk. Women Embracing Islam. Austin, University of Texas Press, 2006.

Caldas-Coulthard, Carmen R., and Rick Iedema. Identity Trouble. Basingstoke: Palgrave Macmillan, 2008.

Clarke, Gerard. "Faith Matters: Faith-Based Organisations, Civil Society and International Development." Journal of International Development 18 (2006): 835-848. 
Clarke, Gerard. “Agents of Transformation? Donors, Faith-Based Organisations and International Development.” Third World Quarterly 28 (2007): 77-96.

Cohen, William B. “The European Comparison.” Ed. Lawrence J. Friedman and Mark D. McGarvie. Charity, Philanthropy, and Civility in American History. Cambridge: Cambridge University Press, 2003. 385-412.

Ferris, Elizabeth. "Faith-based and secular humanitarian organizations" International Review of the Red Cross 87 (2005): 311-325.

“GDN Case Study:”Holistic Care: Heart for Lebanon's Unique Role in the Syrian Refugee Crisis." Heart for Lebanon. Heart for Lebanon, n.d. Web. 15 July 2015.

Green, Tim. "Identity Choices at the Border Zone.” Ed. David Greenlee. Longing for Community: Church, Ummah, or Somewhere in Between? Pasadena, CA: William Carey Library, 2013. 53-66.

Iannaccone, Laurence R. "Risk, Rationality, and Religious Portfolios.” Economic Inquiry XXXIII (1995): 285-297.

James, Rick. "Handle with care: engaging with faith-based organisations in development." Development in Practice 21 (2011): 109-117. 
Jayasinghe, Saroj. "Faith-based NGOs and healthcare in poor countries: a preliminary exploration of ethical issues.” Journal of Medical Ethics 33 (2007): 623-626.

Jindra, Ines W. "How Religious Content Matters in Conversion Narratives to Various Religious Groups.” Sociology of Religion 72 (2011): 275-302.

Jones, Ben, and Marie Juul Petersen. "Instrumental, Narrow, Normative? Reviewing recent work on religion and development.” Third World Quarterly 32 (2011): 1291-1306.

Jindra, Ines W. A New Model of Religious Conversion. Leiden, The Netherlands: Koninklijke Brill NV, 2014.

Kirmani, Nida. "The role of religious values and beliefs in charitable and development organisations in Karachi and Sindh, Pakistan” Development in Practice 22 (2012): 735-748.

Kraft, Kathryn. Searching for Heaven in the Real World. Oxford: Regnum Books International, 2012.

Lynch, Cecelia. "Religious Humanitarianism and the Global Politics of Secularism” Ed. Craig Calhoun, Mark Juergensmeyer, and Jonathan VanAntwerpen. Rethinking Secularism. Oxford: Oxford University Press, 2011. 204-224.

Modood, Tariq. "Culture and Identity" Ed. Tariq Modood and Richard Berthoud. Ethnic Minorities in Britain. London: Policy Studies Institute, 1997. 290-338. 
Morrow, Fr. Patrick. "Christian Understandings of the 'Other': An Unfashionable Defence of Karl Rahner's 'Anonymous Christians'." International Conference on New Neighbours, New Opportunities: The Challenges of Multiculturalism and Social Responsibility. 1-4 July, 2012, Manchester: ICCJ.

Rambo, Lewis Ray, and Charles E. Farhadian. The Oxford Handbook of Religious Conversion. Oxford: Oxford University Press, 2014.

Thanggaraj, M. Thomas. "Defining Religious Conversion.” Ed. Shanta Premawardhana. Religious Conversion: Religion Scholars Thinking Together. Chichester, West Sussex: World Council of Churches Publications, 2015. 21-31.

Raj, Fr. John Felix. "Jesuits at the Mughal court." The Goethals Indian Library and Research Society. Goethals, n.d. Web. 16 July 2015.

Roy, Olivier. Globalised Islam: The Search for a New Umma. London: Hurst and Company, 2004.

Smith, Jackie, and Tina Fetner. "Structural Approaches in the Sociology of Social Movements." Ed. Bert Klandermans and Conny Roggeband. Handbook of Social Movements Across Disciplines. New York: Springer, 2007.

Travisano, Richard. "Alteration and conversion as qualitatively different transformations." Ed. G.P. Stone and H. Faberman. Social Psychology Through Symbolic Interactionism. Waltham, MA: Ginn-Blaisdell, 1970. 
Türk, Volker, José Riera, and Marie-Claude Poirier. "Partnership Note on Faith-based Organizations, Local Faith Communities and Faith Leaders." Geneva: UNHCR, 2014.

van Nieuwkerk, Karin. Women Embracing Islam. Austin: University of Texas Press, 2006.

Wessells, Michael, and Alison Strang. "Religion as Resource and Risk: The double-edged sword for children in situations of armed conflict." Ed. Neil Boothby, Alison Strang and Michael Wessells. A World Turned Upside Down. Bloomfield CT: Kumarian Press, 2006.

Zinnbauer, Brian J., and Kenneth I. Pargament. "Spiritual Conversion: A study of Religious Change among College Students.” Journal for the Scientific Study of Religion 37 (1998): 161-180. 